\title{
Assessing the Extension Staff Farm Visits Frequency Effect on Greenhouse Technology Performance in Small Scale Farms in Gusii Highlands, Kenya
}

\author{
Philip Alinyo Omoro', Anakalo Shitandi2 ${ }^{2}$, Nemwel N. Aming'a², Evans Basweti ${ }^{3}$ \\ ${ }^{1}$ Sub-County Agriculture Office, Ministry of Agriculture Livestock and Fisheries, Ikonge, Kenya \\ ${ }^{2}$ Research and Extension Office, Kisii University, Kisii, Kenya \\ ${ }^{3}$ Faculty of Agriculture \& Natural Resources Management, Kisii University, Kisii, Kenya \\ Email: ${ }^{*}$ ashitandi@gmail.com
}

Received 24 January 2015; accepted 8 February 2015; published 15 February 2015

Copyright (C) 2015 by authors and OALib.

This work is licensed under the Creative Commons Attribution International License (CC BY). http://creativecommons.org/licenses/by/4.0/

(c) (i) Open Access

\section{Abstract}

Purpose: The study aimed at assessing the extension staff farm visits frequency effect on greenhouse technology performance in small scale farms in Gusii Highlands, Kenya. Research Methodology: The study employed a survey research design. The target population for the study was 1000 farmers practising greenhouse technology in Gusii Highlands (Kisii and Nyamira Counties). Purposive and multi-stage sampling techniques were used to sample 276 respondents from the target population. Primary data were collected using questionnaires and key informant interviews. Data was analysed using Microsoft excel and SPSS software. Regression analysis was conducted to determine the relationship between extension staff farm visit frequency and greenhouse technology performance. Findings: The study found out that extension staff farm visit frequency had a significant effect on technology performance ( $t$-value of 7.066 and significance level 0.000 ) that is, there was a positive relationship between extension staff visit frequency and greenhouse technology performance, with an increase of extension staff farm visit by one resulted in an increased performance in tomato production by $305.97 \mathrm{~kg}$. Practical Implications: There is need for extension support in terms of staff capacity building, mobility and employment to improve farmer coverage staff: farmer. Other identified constraints facing smallholder farmers investing in the technology like soil sampling and analysis, irrigation and water management, need to be addressed if green house technology performance is to be improved. Originality: The article presents actual data collected from famers in Gusii Highlands. Assessing the extension staff farm visits frequency effect on greenhouse technology performance in small scale farms in the Gusii Highlands.

\footnotetext{
${ }^{*}$ Corresponding author.
}

How to cite this paper: Omoro, P.A., et al. (2015) Assessing the Extension Staff Farm Visits Frequency Effect on Greenhouse Technology Performance in Small Scale Farms in Gusii Highlands, Kenya. Open Access Library Journal, 2: e1135. 


\title{
Keywords
}

\section{Assessment, Greenhouse, Performance, Technology, Extension, Production}

\author{
Subject Areas: Agricultural Science, Biotechnology
}

\section{Introduction}

Extension is described as "a system that facilitates the farmers' access to knowledge, information and technologies, facilitates their interaction with partners in research, education, agribusiness, and other relevant institutions; and assists them to develop their own technical, organizational and management skills and practices" (University of Greenwich, 2011) [1]. Agricultural extension is the term used to describe the process by which rural people are persuaded to adopt improved farming methods to improve crop and livestock productivity (NALEP, 2011) [2]. The meaning of the term "extension" has changed over time (Swanson, 2008) [3] and is moving away from contemporary emphasis on technology transfer towards a much broader concept that includes developing the skills and management capacities of farmers and the learning capacity of both farmers and extension providers. Agricultural extension provides the bridge between research stations and farmers, carrying and bringing back knowledge based on local experience for further investigation (NALEP, 2011) [2]. The role of extension service in enhancing the adoption and performance of an innovation cannot be overemphasized. Extension services are essential in enabling smallholder farmers' access to technology and knowledge. For this to take place extension materials should be periodically reviewed to meet the changes in technology and farmers demands (Muturi, 1999) [4]. Greenhouse technology for instance requires specialized operation and control hence equally special extension staff support for farmers to succeed (Janick, 1963) [5]. Extension staff plays a facilitating role to support multi-stakeholder innovation processes. In many cases, extension is the only available agricultural information system that actively facilitates adoption of agricultural technologies among smallholders.

Extension is viewed differently by various players; some players view extension as a political rural campaigning tool, others commercial promotion of specific commodity production while others as social aims of promoting and implementing poverty reducing programmes among the rural poor. Extension aims at developing a community or a farmer or a farming system that could improve the social and economic well being of the society. Extension emphasizes improvement of peoples' overall capacity to help themselves. It provides rural people with the access to knowledge and information they need to increase productivity and sustainability of their farming systems. This ultimately improves their quality of life and livelihoods through transfer of information, knowledge and skills. It has helped countries move towards meeting food needs, conserving natural resources and developing human and social capital (Klaus and John, 2010) [6]. Although the role of extension support has been recognized worldwide, it has produced variable results in terms of adoption of recommended practices, increased productivity or impact on rural poverty. This could be necessitated by first, top-down blanket recommendations, as opposed to more narrowly targeted recommendations. Secondly, lack of flexibility and failure to cater for local requirements, thirdly, technologies that are not suitable for the resource-poor and failure to link recommendations to market realities and farmer needs. Finally, weak communication and linkage among farmers, public and private sector extension service providers. The foregoing factors have led to the recent criticism on public extension due to its budgetary requirements, top-down approaches, rigidity and failure to meet the test of time of ever evolving social setting of agricultural households (Tsakani, 2010) [7]. However, in recent years, more attention has been paid to the building capacity of public extension providers, regarding their incentive systems, learning capacity, range of expertise (including marketing and farmer facilitation) and relationships with other related stakeholders, such as research organizations, non-government organizations (NGOs) and agricultural service providers in the private sector (Klaus and John, 2010) [6].

In order to enhance performance of extension service, various approaches have been used; emphasis of development of human capital, participatory approaches which encourages group social mobilization, and household differentiation to bring into focus social and economic aspects of the household with respect to their skills base, the strength of their voice in development and decision making (Klaus and John, 2010) [6]. Extension should also be viewed as an innovation rather than contemporary extension service. Partners and governments 
should develop such principles as; "Freedom of thinking" to eliminating thinking barriers. "Personal aspiration" to enabling self-motivation, "Resource endowment"-making money and other resources available for innovation projects "Incentives"- such as prizes and award systems and "Teamwork"-assembling and managing groups of people with common aims (LEAD, 2003) [8]. (Lamboll et al., 2011) [9] contends that Africa's population is projected to double to two billion people by 2050, and food production will need to double in order to meet the needs of the increasing population, this calls for highly innovative ideas that will lead to increased agricultural productivity. Agriculture, which is a backbone of most African countries is faced by a number of challenges including climate change, and high food demands precipitated by the rapidly increasing population which hampers availability of inputs such as land as a result adversely affecting food production.

New innovative agricultural technologies that will improve food productivity, ensure profitability and sustainability will be required if the ever increasing food demands are to be met. Green house technology has been touted has one of the innovative agricultural technologies that are highly productive and profitable. Globally, they are used in production of high value horticultural crops. The most common type of greenhouse used for farming is the simple tunnel type greenhouses which are used without any detailed environmental control equipment. Over fifty (50) globally practice greenhouse commercial cultivation. The area under greenhouses in Spain is used mostly for growing vegetable crops like watermelon, capsicum, strawberries, beans, cucumbers and tomatoes. The global figures of major countries practicing greenhouse farming are led by China which has 2.76 million hectares, Netherlands 89,600 ha, Korea 57,444 ha, Spain 52,170 ha, Japan 49,049 ha, Turkey 33,515 ha, Italy 26,500 ha, Mexico 11,759 ha, France 9620 ha, and United States of America 8425 ha (Kacira, 2011) [10], to mention just but few. In Canada, the greenhouse industry caters both to the flower and off-season vegetable markets. The Netherlands is the major traditional exporter of greenhouse grown flowers and vegetables all over the world. With about 89,600 ha under cover, the Dutch greenhouse industry is perhaps the most advanced in the world. Data on area under greenhouse farming in Southern and East African countries is scanty as no documentation by countries concerned has been undertaken resulting in lack of information for comparison.

The Kenyan horticultural industry has grown tremendously in the recent past in terms of foreign exchange earnings, family income, employment creation and other indirect effects which contribute to economic growth (HCDA, 2010) [11]. This is in line with the government strategy that agriculture sector ministries are to ensure that farmers, producers, processers and marketers of agricultural produce employ the most contemporary methods and technologies. This requires that all agricultural enterprises be highly productive, commercial in nature and competitive at all levels (GOK, 2010) [12]. In addition, horticultural production is practiced in most regions in the country with a high prevalence in the private sector. Through its vibrant growth in the last decade, the sub-sector has also been accredited for improved rural incomes hence reducing poverty directly or indirectly (Mutuku et al., 2004) [13]. It is estimated that horticulture sub-sector in Kenya employs approximately 4.5 million people directly in production, processing, and marketing, while another 3.5 million people are employed indirectly through trade and other activities (World Bank, 2010) [14]. Horticulture is one of the leading agricultural sub-sectors in income generation, contributing at least KES 120 billion (\$1.85 billion) in 2009 (KHDP, 2009) [15]. Horticultural exports from Kenya are mainly destined for European markets, other emerging foreign market outlets include Middle East, South Africa, Norway, USA, Canada and Japan (HCDA, 2007; Minot and Ngigi, 2004) [16] [17]. This has been made possible by implementing ASDS that underscores the need to develop and manage prudently factors of production so that the cost of production is within the international standards (GOK, 2010) [12]. In Kenya, most greenhouses are found in Rift Valley around lake Naivasha and tea estates in Kericho, Nandi hills, Nakuru, Eldoret, Koibatek, Baringo, Nairobi around Athi river and parts of central Kenya region (Thika, Limuru, Embu) where multinational and local companies started large scale flower farming mainly for export market and to small extend local market. Currently, greenhouse farming has spread countrywide with many players promoting the technology as suppliers of materials, equipment and products. They include companies such as Amiran (K), GNorth \& son, GreenTech, Hortec, HortPro, Syngenta, Aqua Clara, Banks and other financial institutions promoting greenhouses for commercial farming. Although horticultural industry has been vibrant in Kenya the growth has largely been seen mainly in central Kenya and some parts of Rift valley. Generally, the technology has enormous potential for growth and production in Kenya. The challenge of youth unemployment is still present in rural Kenya, despite the fact that agriculture supports about 75\% of Kenya's population. This is because Kenya's farming population is ageing (averaging 60 years), implying that agriculture is not a core attraction for the youth (UNDP, 2011) [18]. The potential for widespread adoption of greenhouse technology is still enormous since youths prefer modern farming technologies, with higher returns per unit area 
and regular income. This is the potential for growth in greenhouse farming amongst the youth.

Greenhouse technology was introduced in Gusii Highlands recently (approximately 5 years ago) aiming at increased food production, farm income and overcoming the numerous agricultural challenges (The Organic Farmer, 2011; DAO, Nyamira North Annual Report, 2012) [19] [20]. According to Nyamira county development profile strategy for high impact in poverty reduction programmes, projects and campaigns should target agriculture and enhance value addition, crop diversification and adoption of modern technologies (GOK, 2013) [21]. Uptake of the technology by smallholder farmers has increased as a result of many factors including climate change and high population density which has put pressure on traditional agricultural production systems, research and extension promotion, support from rural development organizations coupled with farmers increased awareness of aspects of commercialization of agricultural production amongst others. This has been achieved through efforts of government agencies such as MoA (NMK, HCDA, SHoMaP and SNCDP/IFAD), MoWI, MoYA, NGOs such as APHIA Plus, World vision, AMREF and USAID-KHCP, Banks and private companies mentioned above. The introduction of greenhouse farming has been received with a mixed reaction while some farmers have appreciated the existence of the technology others have received little or no benefits from the technology. The technology has been used for production of tomatoes only in Nyanza province, since 2006 to 2010 the area under tomato production reduced significantly from 7074 Ha to 5538 Ha while production increased from 141,480 MT to 166,140 MT during the same period (HCDA, 2010) [11]. This can be attributed to increase in the use of greenhouse farming in Nyanza region. Kisii and Nyamira counties are among the six (6) counties in Nyanza region (others are Migori, Homabay, Kisumu and Siaya).

In Kisii and Nyamira counties, there are an estimated two hundred and nine (209) greenhouses involving over one thousand (1000) farmers as individuals and members of groups and institutions practicing greenhouse farming. Eighty-eight (88) units are owned by groups and institutions with an average membership of fifteen (15) farmers each, while one hundred and twenty one (121) units are owned by individual farmers. These greenhouses and the farmers are evenly distributed in the two counties. Kisii County has one hundred and five (105) units distributed in the following sub counties: Gucha sixteen (16), Gucha south three (3), Kenyenya seventeen (17), Kisii central nineteen (19), Kisii south eight (8), Marani three (3), Masaba south twenty-seven (27), Nyamache nine (9) and Sameta three (3). While Nyamira County has one hundred and four (104) units distributed in the following sub counties; Borabu thirty-eight (38), Manga twenty-one (21), Masaba north eight (8), Nyamira seven (7) and Nyamira north thirty (30). The only exception is Borabu Sub County where out of a total of thirty-eight (38) units, two (2) large scale farmers own thirty-one (31) units representing fourteen point eight percent (14.8\%) of the entire study area total greenhouse units. Crops that can be grown in greenhouses include; tomatoes, cucumber, onions, black nightshade, brinjals, butternut, cabbages, capsicums, herbs/spices, water melon, cowpeas, strawberry, flowers to mention but a few (NALEP, 2011) [2]. For high returns to be achieved through greenhouse farming, farmers need to grow high value crops especially $F_{1}$ seeds/varieties which have other benefits. However, it has been noted that tomato is the most commonly grown greenhouse crop. This is because of its competitiveness and comparative advantages. For disease control, and farm rotation plan, other crops are routinely grown in greenhouses despite the fact that their financial returns may be lower compared to tomato. Extension staff visit frequency is expected to positively influence agricultural performance. Results from Kenya indicate that there is no evidence of a significant or sustained impact of extension on agricultural productivity (World Bank, 1999) [22]. While another study by Evenson and Mwabu (1998) [23] found out that farm yields rise as the number of extension staff per farm increases. Implying that if the number of extension visits rise, there is likely improved farm productivity. There is no clear evidence of the effect of extension on farm productivity. Therefore the study aimed at determining the effect of extension staff visits frequency on greenhouse technology performance.

\section{Research Methodology}

\subsection{Study Area Description}

The study was conducted in Kisii and Nyamira Counties which are high agricultural potential areas (MoA, 2009) [24]. The study area covers $2334.2 \mathrm{Km}^{2}$ of which approximately $80 \%$ is arable land. The counties lay between longitudes 340,581E and 350,051E and latitudes 00.351S and 00.883S. This area falls under AEZs LH1, LH2, UM1, LM1 and LM2. The altitude ranges between 1700 - 1800 M ASL. The study area has clay loam soil in most parts. The counties have two rainy seasons; long rains from February to June and short rains from August 
to December with dry spells in January and July. On most occasions, the seasons overlap leading to continuous cropping. The annual rainfall ranges between $1200-2500 \mathrm{~mm}$. The mean temperatures are $20^{\circ} \mathrm{C}-27^{\circ} \mathrm{C}$ (maximum) and $15^{\circ} \mathrm{C}-18^{\circ} \mathrm{C}$ (minimum). Kisii and Nyamira counties are divided into fourteen (14) sub counties; Gucha, Gucha south, Kisii central, Kisii south, Marani, Masaba south, Nyamache, Sameta, Borabu, Masaba North, Nyamira, Nyamira North, and Manga which are further subdivided into 65 wards. The total population is approximately 1,865,149 persons with 193,165 farm families and a household having an average of 6 persons (KNBS, 2009) [25]. There are 149 extension units with average staff: farmer ratio of 1:2500. The average farm size is $0.5-1.5$ Ha with the highest having over 100 Acres (in Borabu) while the lowest is having 0.25 acres (in other sub counties). The major economic activity is agricultural production for food and income. The major crops grown include cash crops such as tea, coffee, bananas, industrial and chewing cane and pyrethrum. Food crops are maize, beans, bananas, sweet potatoes, cassava, sorghum, millet and various fruits and horticultural crops like tomatoes, kales, and indigenous vegetables for both local and export market. Livestock production is dominated by dairy and local poultry. Agriculture employs an estimated $80 \%$ of the population either directly or indirectly. The estimated rural poverty is $30 \%$ with some areas having as high as $61 \%$ according to Kisii and Nyamira counties profiles (MoA, 2012) [26].

\subsection{Sampling and Data Collection Procedures}

The target population of the study was the entire small scale greenhouse farmers in Kisii and Nyamira counties estimated to be approximately one thousand (1000) and who are members of eighty-eight (88) groups and institutions and one hundred and twenty-one (121) as individual farmers. All together they own a total of two hundred and nine (209) greenhouse units in the study area. The study sample size was two hundred seventy-six (276) as dictated by factors such as: research cost, size of the area covered, time, transport and human resources among others. This was as derived from the Morgan table (Krejcie and Morgan, 1970) [27] based on probability proportional to size sampling from practicing greenhouse farming groups, individual greenhouse farmers, input suppliers and extension staff. The study used a purposive and multi-stage sampling technique to select farmers to participate in the study (Mugenda, 1999) [28]. The choice of this technique is guided by the concentration of individual farmers and groups undertaking greenhouse farming and the spread in the study area sub sampled. This was aimed at minimizing errors and provided opportunities to check some of the most likely sources of bias or random error (Dooley, 2001) [29]. First stage is the sub-counties where greenhouse farming is undertaken. The second stage is the division/ward and the third stage is the groups undertaking the farming and the agrodealers. Selection of individual farmers, group members, stockists, and extension staff was undertaken randomly. The main data collection instruments were key informant interview checklist and questionnaires schedules. Key informant interviews and focused group discussions were conducted for agro-dealers and extension staffs at the district and division/ward office. The researcher used interview checklist with open ended questions for cross checking responses given on technology performance related issues by various groups. Questionnaires administered by enumerators were used to collect data at farm level on greenhouse technology performance from farmers. Data on education level and experience, production levels and technological skills, farm input types and use, and challenges facing the target groups was collected. The research instrument content was shared with the supervisors for their necessary input and approval before embarking on field data collection and then pre-tested in a pilot study for validity then finally used. The respondents were informed of the purpose of the interview and the need to respond truthfully. This was to ensure that the data collected by the enumerator is reliable. Data was analysed using Microsoft excel, and SPSS programmes. Linear regression analysis was used to determine the relationship between extension staff visits and technology performance. Findings were further critically analyzed, interpreted and are presented in descriptive statistics and by use of diagraphs e.g. tables, pie charts and bar graphs. The research findings on the fertilizer application rates and its effect on greenhouse technology performance informed the recommendations and way forward on the future of greenhouse technology in the study area and beyond.

\section{Results and Discussions}

\subsection{Description of the Study Sample}

The sample population used in the study was two hundred and seventy-six (276) comprising of one hundred and ninety-eight (198) small scale greenhouse farmers, forty-two (42) farm input suppliers and thirty-six (36) exten- 
sion staff. This was based on number of practicing greenhouse farmer groups, individual greenhouse farmers, farm input suppliers and extension staffing levels. Kisii County contributed 60\% sampled from the following four sub counties Kisii central, Gucha, Kenyenya, and Masaba south due to its larger size compared to Nyamira County 40\% sampled from two sub counties of Manga and Nyamira north. Out of the six (6) sub counties sampled each contributed equal number of respondents; forty-six (46) comprising thirty-three (33) farmers, seven (7) farm input suppliers and six (6) extension staff. Selection of individual farmers, members from groups, stockists and extension staff was done at random. The results of population sample are presented in Table 1.

\subsection{Greenhouse Farmers by Gender and Age as Percentage of Sample Population}

The sample population of 198 greenhouse farmers distribution by gender comprised 62\% (122 males) and 38\% (76 females) while according to age distribution, there were 71\% (142 adults) and 29\% (56 youths). Further analysis of results indicate that for both age groups female farmers were less than males for instance $27 \%$ (female adults) and $11 \%$ (female youths). The results of the findings are presented in Table 2.

The challenge of youth unemployment is still present in rural Kenya, despite the fact that agriculture supports about $75 \%$ of Kenya's population. This is because Kenya's farming population is ageing (averaging 60 years), implying that agriculture is not a core attraction for the youth (UNDP, 2011) [18]. The study findings on gender and age indicate that the uptake of greenhouse technology by youths is on the raise with $29 \%$ of sample population being youths. This confirms that youths prefer modern farming technologies, with higher returns per unit area and regular income such as greenhouse farming technology.

\section{Extension Staff Farm Visit Frequency and the Effect on the Performance}

\subsection{Overall Overview of Their Effect on the Performance}

The study findings on extension staff farm visit frequency and the resultant technology performance indicate a significant (t-value of 7.066 and significance level 0.000 ) $305.97 \mathrm{~kg}$ effect on performance that is a direct and positive relationship. An increase in extension staff farm visit by one resulted in a corresponding $305.97 \mathrm{~kg}$ increase in performance as illustrated in Table 3. This result concurs with findings by (Evenson and Mwabu, 1998) [23] that an increase in the number of extension staff per farm leads to rise in farm yields. Masaba south had the highest figure of extension staff farm visit frequency mean of 5.27 corresponding highest technology performance effect of $6558.50 \mathrm{~kg}$. While Kisii central with the lowest extension staff farm visit frequency mean of 1.77 corresponding to lowest technology performance of $2484.67 \mathrm{~kg}$ with some slight variations which can be attributed to other factors that also affect performance. The study area had extension staff farm visit frequencies mean of 3.09 and with a performance mean of $3890.24 \mathrm{~kg}$. Greenhouse technology requires specialized operation and control hence equally special extension staff support for farmers to succeed (Janick, 1963) [5]. Extension services has helped countries move towards meeting food needs through improved productivity, conserving natural resources and developing human and social capital (Klaus and John, 2010) [6]. Hence, solutions to agricultural productivity lie in viewing the drivers of agricultural productivity holistically (UNDP, 2012) [30]. The study findings are as presented in summary in Table 3;

\subsection{Counties Extension Staff Farm Visit Frequency Effect on the Performance}

\subsubsection{Kisii County Extension Staff Farm Visit Frequency Effect on the Performance}

Kisii County had extension staff farm visit frequency mean of 3.33 and technology performance mean of $4241.78 \mathrm{~kg}$. Sub counties extension staff farm visit frequency means and effect on performance in decreasing order were Masaba south with highest mean of 5.27 and $6558.50 \mathrm{~kg}$, Kenyenya 3.90 and $5352.47 \mathrm{~kg}$ Gucha 2.37 and $2571.47 \mathrm{~kg}$ and Kisii Central lowest mean of 1.77 and $2484.67 \mathrm{~kg}$ as presented in summary in Table 4.

\subsubsection{Nyamira County Extension Staff Farm Visit Frequency Effect on the Performance}

Nyamira County had an extension staff farm visit frequency mean of 2.66 and a technology performance mean of $3187.18 \mathrm{~kg}$. The sub county of Nyamira north had a higher extension staff farm visit frequency mean of 3.10 and performance of $3436.98 \mathrm{~kg}$ compared to Manga of 2.13 and $2937.37 \mathrm{~kg}$ respectively as presented in summary in Figure 1. 
Table 1. Distribution of study sample population per county.

\begin{tabular}{cccc}
\hline County & Sub County & Frequency & Percentage \\
\hline Kisii & Kisii Central, Gucha Kenyenya, Masaba S & 166 & 60 \\
Nyamira & Manga, Nyamira North & 110 & 40 \\
& Total & $\mathbf{2 7 6}$ & $\mathbf{1 0 0}$ \\
\hline
\end{tabular}

Table 2. Distribution of greenhouse farmers by gender and age as \% of sample population.

\begin{tabular}{ccccc}
\hline Gender & Frequency & Sub Total & Percentage & 44 \\
Male Adult & 87 & & 27 & 71 \\
Female Adult & 55 & 142 & 18 & 11 \\
Male Youth & 35 & 56 & & \\
Female Youth & 21 & & $\mathbf{1 0 8}$ & \\
Total & & & $\mathbf{1 0 0}$ \\
\hline
\end{tabular}

Table 3. Extension staff farm visit frequency and effect on the performance.

\begin{tabular}{ccc}
\hline Sub County & Extension Visits & Mean Performance (kg) \\
\hline Nyamira North & 3.10 & 3436.98 \\
Kisii Central & 1.77 & 2484.67 \\
Gucha & 2.37 & 2571.47 \\
Manga & 2.13 & 2937.37 \\
Masaba South & 5.27 & 6558.50 \\
Kenyenya & 3.90 & 5352.47 \\
\hline
\end{tabular}

Table 4. Kisii County extension staff farm visit frequency effect on the performance.

\begin{tabular}{ccc}
\hline Sub County & Extension Visits & Mean Performance (kg) \\
\hline Kisii Central & 1.77 & 2484.67 \\
Gucha & 2.37 & 2571.47 \\
Masaba South & 5.27 & 6558.50 \\
Kenyenya & 3.90 & 5352.47 \\
Combined & 3.33 & 4241.78 \\
\hline
\end{tabular}

Extension visits
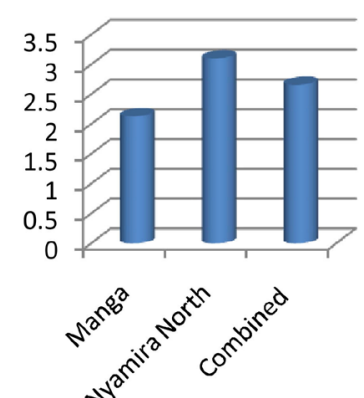

Performance kg

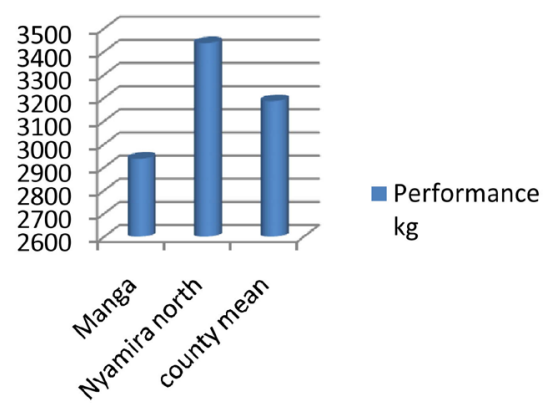

Figure 1. Nyamira County extension staff farm visit frequency and the performance.

4.2.3. Counties Comparison of Extension Staff Farm Visit Frequency and the Performance

The study findings show that the two counties had a mean of 3.09 of extension staff farm visit frequency and technology performance mean of $3890.24 \mathrm{~kg}$ while Kisii had a higher mean of 3.33 and $4241.78 \mathrm{~kg}$ than Nyamira of 2.62 and $3187.18 \mathrm{~kg}$ as presented in summary in Table 5. 
Table 5. Counties comparison of extension staff farm visit frequency and the performance.

\begin{tabular}{ccc}
\hline County & Extension Visits & Mean Performance (kg) \\
\hline Kisii & 3.33 & 4241.78 \\
Nyamira & 2.62 & 3187.18 \\
Combined & 3.09 & 3890.24 \\
\hline
\end{tabular}

\section{Conclusions and Recommendations}

\subsection{Conclusions}

Extension staff farm visit frequency had a significant (t-value 7.066 and sign level 0.000) effect on technology performance. An extension staff farm visit frequency increase by one increased technology performance by $305.97 \mathrm{~kg}$. The results indicate a direct and positive relationship with the highest number of extension visit frequency mean of 5.27 corresponding to highest technology performance of $6558.50 \mathrm{~kg}$ and extension staff farm visit frequencies mean of 3.09 and with a performance mean of $3890.24 \mathrm{~kg}$. While the lowest extension visit frequency mean of 1.77 corresponding to lowest technology performance of $2484.67 \mathrm{~kg}$ with some slight variations which can be attributed to other factors that affect performance. The conclusion drawn from study findings is that there is need for extension support in terms of staff capacity building, mobility and employment to improve staff: farmer ratio and farmer coverage.

\subsection{Recommendations}

From the study findings the following recommendations are made to improve greenhouse technology performance in small scale farms in Kisii and Nyamira Counties and other areas with similar physical and socio-economic environmental conditions. The recommendations have cross cutting implications on extension, policy and research. Greenhouse technology is capital intensive venture and requires high level of management from farmers for corresponding results in terms of crop yield and quality. Since performance results are low and according to logic model and on the expected logical relationships between the inputs, outputs, outcomes, impact all contribute to the current situation. Ministry of agriculture and all concerned authorities involved in technology development and dissemination need to carry out a SWOT analysis and address gaps that are likely to emerge. There are many players involved in emerging agricultural technologies development and dissemination from both the private and public sectors including enterprises value chain players. A coordinated approach with structures and systems in place is needed to avoid giving farmers contradicting and conflicting information and documenting progress. Currently, there is no documented data on the national greenhouse status. There is need to develop standard extension package for use by all stakeholders promoting greenhouse technology and to build capacity among extension staff to pass quality information to greenhouse farmers on all aspects of management. To improve farmer coverage there is need to employ more extension staff and improve their mobility.

\subsection{Suggestion for Further Research}

Other factors affecting greenhouse technology performance that were not covered in this study such as water and irrigation, soil sampling and analysis, structural design among others need to be addressed since solutions to agricultural productivity lie in viewing the drivers of agricultural productivity holistically. Kisii central sub county performance results and extension visits were lowest in the study area despite the fact it has a comparative and competitive advantage over the rest in terms of proximity to market, credit institutions, and inputs suppliers, good infrastructure as well as agriculture extension staff coverage in terms of numbers. Effectiveness of extension services in Kisii central sub county needs to be evaluated.

\section{Acknowledgements}

The authors are grateful to Dr. Maobe for his advice and comments throughout the study, Kisii University for granting the research facility and the Ministry of Agriculture for granting approval to the first author. We also thank the agriculture extension staff, stockiest and farmers in Kisii and Nyamira counties, Kenya, who facilitated as enumerators and provided vital data as key informants and respondents during the field work. 


\section{References}

[1] University of Greenwich (2011) Agricultural Extension Advisory Services and Innovation. http://www.nri.org

[2] NALEP (National Agriculture and Livestock Extension Programme) (2011) A Guide to Effective Extension Methods for Different Situations. NALEP, Nairobi.

[3] Swanson, B.E. (2008) Global Review of Good Agricultural Extension and Advisory Services Practices. Food and Agriculture Organization, Rome.

[4] Muturi, S.N. (1999) Agroforestry Extension Manuals. A Survey of Their Use in Kenya. Technical Report No. 21. Swedish International Development Cooperation Agency.

[5] Janick, J. (1963) Horticultural Science. Purdue University, Indiana.

[6] Klaus, D. and John, O. (2010) Capital Market Access, Factor Demand, and Agricultural Development in Rural Areas of Developing Countries: The Case of Uganda. World Bank and Economic Policy Research Center. http://www.worldbank.org

[7] Tsakani, N. (2010) From a Deficit-Based to an Appreciative Inquiry Approach in Extension Pragrams: Constructing a Case for a Positive Shift in the Current Extension Intervention Paradigm. Journal of International Agricultural and Education Extension, 17, 57-68.

[8] LEAD International (2003) Invention and Innovation for Sustainable Development. A Report of a Workshop Sponsored by the Lemelson-MIT Program and LEAD International, London. http://lemelson.mit.edu/

[9] Lamboll, R., Nelson, V. and Nathaniels, N. (2011) Emerging Approaches for Responding to Climate Change in African Agricultural Advisory Services: Challenges, Opportunities and Recommendations for an AFAAS Climate Change Response Strategy. AFAAS, Kampala and FARA, Accra.

[10] Kacira, M. (2011) Greenhouse Production in US: Status, Challenges, and Opportunities. Presented at CIGR 2011 Conference on Sustainable Bio-Production WEF 2011, Tokyo, 19-23 September 2011.

[11] HCDA (Horticultural Crops Development Authority) (2010) Horticultural Crops Production Report. http://www.hcda.or.ke

[12] GOK (Government of Kenya) (2010) Agricultural Sector Development Strategy (ASDS) 2010-2020. Ministry of Agriculture, Nairobi.

[13] Mutuku, M., Tschirley, D. and Michel, T.W. (2004) Improving Kenya’s Domestic Horticultural Production and Marketing Systems: Current Competitiveness, Forces of Change, and Challenges for the Future. Tegemeo Institute of Agricultural Policy and Development. Working Paper No.08B/2004. Vol. II. Horticultural Marketing.

[14] World Bank (2010) Kenya Economic Update. http://www.worldbank.org/kenya/keuon22/10/2013

[15] KHDP (Kenya Horticultural Development Programme) (2009) Update on Kenyan Horticulture. http://www.fintrack.com

[16] HCDA (Horticultural Crops Development Authority) (2007) Export Statistics in Volumes and Values for Fresh Fruits, Flowers and Vegetables for the Year 2007 in Kenya.

[17] Minot, N. and Ngigi, M. (2004) Are Horticultural Exports a Replicable Success Story? Evidence from Kenya and Côte d’Ivoire. EPTD Discussion Paper No. 120. International Food Policy Research Institute, Washington DC.

[18] UNDP (United Nations Development Programme) (2011) Development of Short Term Training Modules to Respond to Selected Skill Gaps for Agri-Business. http://www.ke.undp.org.

[19] The Organic Farmer (2011) The Other Side of Greenhouses. Issue No. 77.

[20] DAO (District Agriculture Officer) (2012) Nyamira North Annual Report. Ministry of Agriculture, Nairobi.

[21] GOK (Government of Kenya) (2013) Nyamira County Development Profile. Ministry of Agriculture, Nairobi.

[22] WB (World Bank) (1999) Agricultural Extension. The Kenya Experience. World Bank Operations Evaluation Department Report Number 198.

[23] Evenson, R.E. and Mwabu, G. (1998) The Effects of Agricultural Extension on Farm Yields in Kenya. Economic Growth Center, Center Discussion No. 798.

[24] MoA (Ministry of Agriculture) (2009) Farm Management Handbook of Kenya Vol. II Natural Conditions and Farm Management Information. 2nd Edition, Part a West Kenya Subpart A2 Nyanza Province MoA Kenya in Cooperation with GTZ. Ministry of Agriculture, Nairobi.

[25] KNBS (Kenya National Bureau of Statistics) (2009) National Housing and Population Census 2009. Volume 1. Republic of Kenya, Nairobi. 
[26] MoA (Ministry of Agriculture) (2012) Annual Work Plan: Kisii County. Ministry of Agriculture, Nairobi.

[27] Krejcie, R. and Morgan, D. (1970) Determining Sample Size for Research Activities. Educational and Psychological Measurement, 30, 607-610.

[28] Mugenda, O.M. and Mugenda, A.G. (1999) Research Methods: Quantitative and Qualitative Approaches. Acts Press, Nairobi.

[29] Dooley, D. (2001) Social Research Methods. 4th Edition, University of California, Irvine.

[30] UNDP (United Nations Development Programme) (2012) African Human Development Report 2012. Towards a Food Secure Future. Colorcraft, New York. 
Scientific Research Publishing (SCIRP) is one of the largest Open Access journal publishers. It is currently publishing more than 200 open access, online, peer-reviewed journals covering a wide range of academic disciplines. SCIRP serves the worldwide academic communities and contributes to the progress and application of science with its publication.

Other selected journals from SCIRP are listed as below. Submit your manuscript to us via either submit@scirp.org or Online Submission Portal.
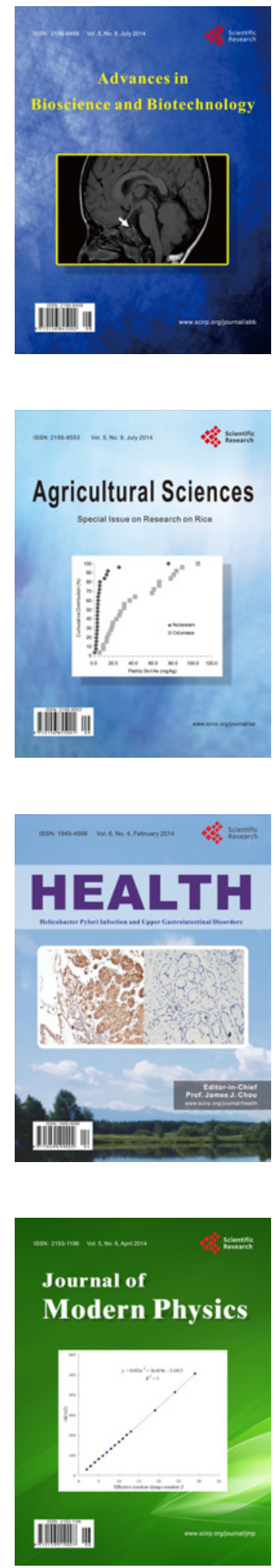
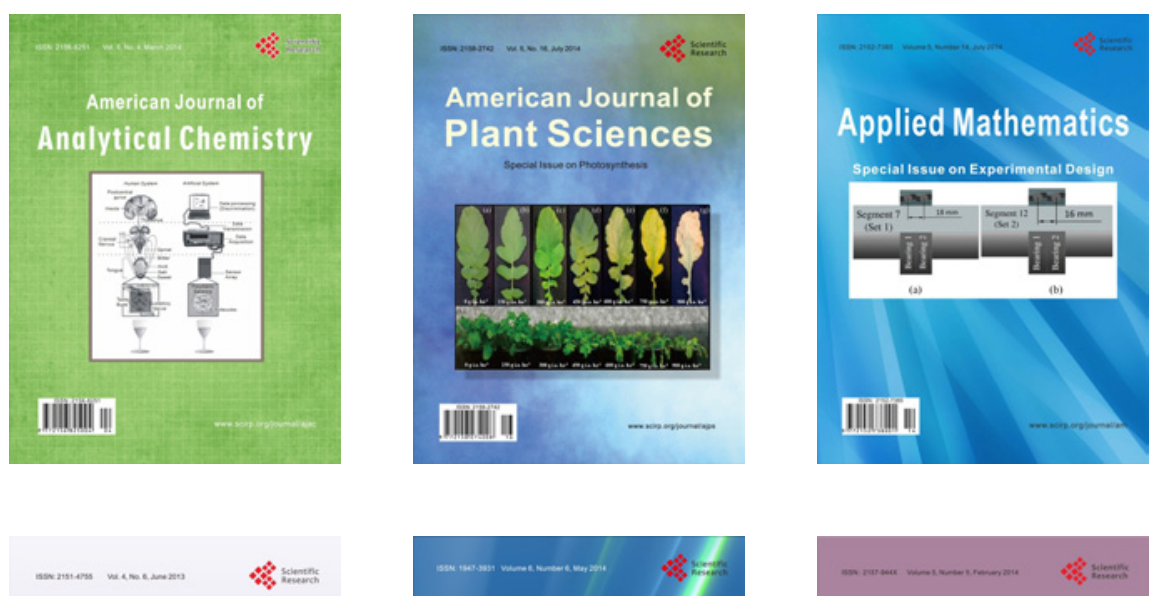

Creative Education
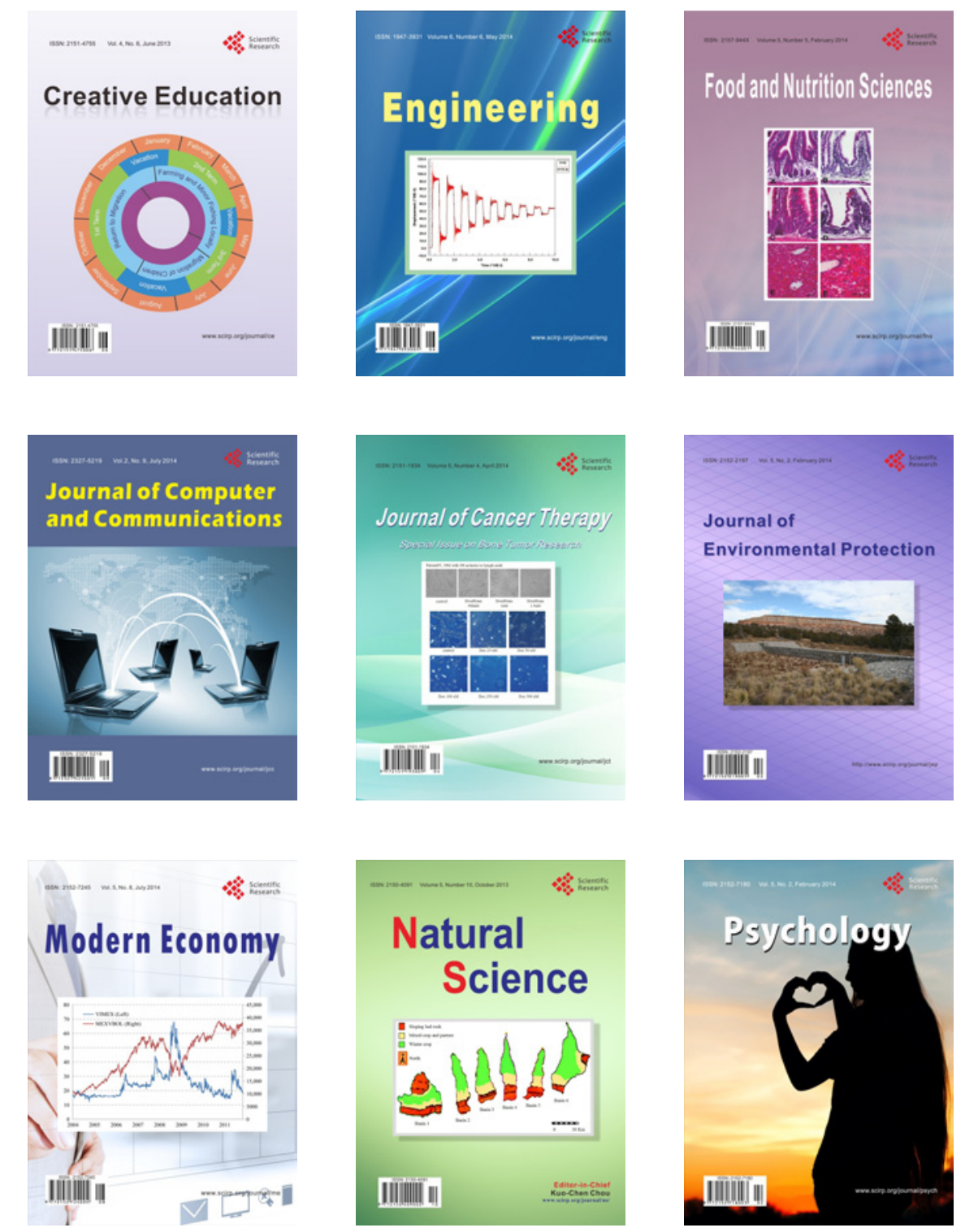